\title{
Laboratory Evaluation of the Effect of Egyptian Native Plants Against Some Parasitic Vectors
}

\author{
Mısır'daki Yerli Bitkilerin Bazı Parazitik Vektörlere Karşı Olan Etkisinin \\ Laboratuvarda Değerlendirilmesi
}

\author{
Eman Taher ${ }^{1}$, Narmeen Mahmoud', Maha Mahmoud² \\ ${ }^{1}$ Clinic of Parasitology, Research Institute of Ophthalmology, Giza, Egypt \\ 2Department of Zoonoses, Faculty of Veterinary Medicine, Cairo University, Cairo, Egypt
}

\section{ABSTRACT}

Objective: Four plant extracts possessing molluscicidal and insecticidal efficacy were evaluated under laboratory conditions versus Biomphalaria alexandrina, Lymnea cailliaudi snails, their egg masses and Culex pipiens larvae. These extracts included Grape seed, Eucalyptus, Pomegranate, Verbesina alcoholic extracts, as well as Eucalyptus oil.

Methods: Different mortalities in the exposed vectors were recorded due to the four plant extracts using different concentrations and exposure time.

Results: Total snail mortality LC 100 was (100 ppm/12-24h) for Grape seed, (200 ppm/18-24h) for Eucalyptus, (100 ppm/12-18h) for Pomegranate, (100-200 ppm/24h) for Verbesina alcoholic extracts and (100-200 ppm/12h) for Eucalyptus oil. However, only Eucalyptus, Verbesina alcoholic extracts and Eucalyptus oil revealed snail ovicidal effects. LC 100 was (100-200 ppm/24h), (100-200 ppm/24h) \& (100-200 ppm/12-48h) respectively. Moreover, the same plant extracts were able to induce total Culex pipiens larvicidal mortality, LC 100 was (200 ppm/48h). However, Grape seed and Pomegranate alcoholic extracts did not induce either snail ovicidal or Culex pipiens larvicidal total mortalities. Activities of the studied plant extracts were considered using reference molluscicidal (Copper sulfate) and insecticidal (Temephos) substances. Conclusion: Egyptian native plants continue to provide a wealth of potential sources for biologically active agents that may have a promising role in the production of safe, biodegradable eco-friendly and natural molluscicidal and insecticidal agents.

(Turkiye Parazitol Derg 2012; 36: 160-5)

Key Words: Molluscicides, insecticides, grape seed, eucalyptus, pomegranate, Verbesina, Biomphalaria alexandrina, Lymnea cailliaudi, Culex pipiens

Received: 24.02 .2012

Accepted: 10.05 .2012

\section{ÖZET}

Amaç: Mollosidal ve insektisidal etki gösteren dört bitki ekstratı laboratuvar koşulları altında Biomphalaria alexandrina, Lymnea cailliaudi salyangoz türleri, bunların yumurtaları ve Culex pipiens'in larvalarına karşı olan etkinlikleri açısından değerlendirilmiştir. Bu ekstraktlar, üzüm tohumu, ökaliptus, nar ve Verbesina'nın alkol ekstraktları ve ökaliptus yağıdır

Yöntemler: Farklı konsantrasyonlar ve farklı sürelerde bu bitki ekstraktlarına maruz bırakılan vektörlerde farklı ölüm oranları elde edilmiştir. Bulgular: Salyangozlardaki toplam ölüm oranları $\left(\right.$ LC $\left._{100}\right)$ üzüm tohumu için 100 ppm/12-24saat, ökaliptus için 200 ppm/18-24saat, nar için 100 ppm/12-18saat, Verbesina için 100-200 ppm/24saat ve ökaliptüs yağı için 100-200 ppm/12saat olarak belirlenmiştir. Ancak sadece ökaliptus $\left(L_{100}=100-200\right.$ ppm/24saat) ve Verbesina $L_{100}=100-200$ ppm/24saat) alkol ekstraktları ile ökaliptus yağı $\left(L C_{100}=100-200\right.$ ppm/12-48saat) salyangoz yumurtaları üzerine öldürücü etki göstermiştir. Bundan başka bazı bitki ekstraktları C. pipiens larvaları üzerine olan öldürücü etkiyi indüklemiştir $\mathrm{LC}_{100}=200$ ppm/48saat). Bununla birlikte, üzüm tohumu ve nar alkol ekstratkları ne salyangoz yumurtaları üzerine ne de C. pipi-

Address for Correspondence / Yazışma Adresi: Dr. Eman Taher, Clinic of Parasitology, Research Institute of Ophthalmology, Giza, Egypt E-mail: eman_taher@yahoo.com doi:10.5152/tpd.2012.38 
ens larvaları üzerine etkili olmamıştır. Çalışılan bitki ekstraktlarının aktiviteleri referans mollusid (bakır sülfat) ve insektisit (Temefos) maddelere benzer olarak değerlendirilmiştir.

Sonuç: Mısır'daki yerli bitkilerin biyolojik olarak aktif vektörler için zengin potansiyel kaynaklar olduğu, güvenli, biyolojik olarak yıkılabilir, çevreye dost ve doğal mollusid ve insektisisidal ajanlar üretilebileceği görülmüştür. (Turkiye Parazitol Derg 2012; 36: 160-5)

Anahtar Sözcükler: Mollusid, insektisit, üzüm tahomu, ökaliptus, nar, Verbesina, Biomphalaria alexandrina, Lymnea cailliaudi, Culex pipiens

\section{INTRODUCTION}

Phytomedicine has been used to treat parasitism. Moreover; many modern commercial medicines are derived from plants. However, scientific evidence on the anti-parasitic efficacy of most plant products are limited (1). The use of natural products of plant origin (botanical derivatives) is a recent alternative approach for mosquito and snail control. In spite their toxicity to pests and snails, they are readily biodegradable and usually lack toxicity to higher animals' which means that they are eco-friendly (2).

Culex pipiens mosquito, Biomphalaria alexandrina and Lymnea cailliaudi snails are major pests of medical importance having different roles in transmitting many diseases (3).

Mosquitoes can transmit dreadful and fatal diseases to more than 700 million people, such as malaria, dengue, yellow fever, and filariasis (4). In various areas of the world, mosquitoes have been found to become resistant to several of the biological and conventional chemical insecticides used for their control (5).

Schistosomiasis is an important disease in Egypt and other tropical countries (6). It is considered as the world's most widespread parasitic disease (7). More than 207 million people are infected worldwide (8). A sure way to tackle the problem of diseases transmitted through snails as intermediate hosts is to destroy the carrier snails and remove an essential link in the lifecycle by using molluscicide (9). This type of control appears feasible and cost effective especially in poor countries (10). However, synthetic organic molluscicides are toxic to non-target animals and may have long term effects on the aquatic environment (9).

In this respect, the present work is an attempt to evaluate molluscicidal and or insecticidal properties of Grape seed extract, Pomegranate, Verbesina, Eucalyptus alcoholic extracts and Eucalyptus oil for their effect on B. alexandrina (vector of Schistosoma mansoni), L. cailliaudi (vector of Fasciola gigantica) snails and their egg masses as well as on larvae of Culex pipiens.

\section{METHODS}

\section{Plant material}

Grape seeds the fruit of Vistis vinifera, Eucalyptus, Pomegranate the fruit of Punica granatum L., and Verbesina alternifolia, were collected from different areas from Egypt, during 2010. Plants were washed with tap water and dried at room temperature. The air-dried powdered parts were exhaustively extracted with $90 \%$ ethanol by maceration. The total alcoholic extract was combined and evaporated under reduced pressure by vacuum distillation at a temperature not exceeding $40^{\circ} \mathrm{C}$ to yield a semi-solid residue. Essential oil extract was obtained by hydrodistillation for 2 hours using a Clevenger-type apparatus using the methods of
Cetin and Yanikoglu (11). Investigation of the prepared oils was carried out on an Agilent (USA) GC-MS system. The extracts and oil were concentrated and stored in dark glass tubes under refrigeration at $\left(4^{\circ} \mathrm{C}\right)$ until evaluation (12).

\section{Tested Snails \&their Egg Masses}

Biomphalaria alexandrina and Lymnea cailliaudi snails $(5-6 \mathrm{~mm})$ were collected from irrigation canals in Giza Governorate. Snails were identified according to Christensen and Frandson (13). They were screened for natural infection with any trematodes. Uninfected snails that didn't harbor any trematoda parthenata were maintained in the laboratory conditions in fresh de-chlorinated tap water fed with fresh lettuce leaves with daily cleaning for at least 7 days before using in the experiment. Snails were prevented from crawling out of the solution by means of a fine mesh placed above the water surface.

Snail aquaria were supported by cellophane sheet for egg deposition. Freshly laid, 3-5 days old B. alexandrina and Lymnea cailliaudi egg masses were collected. Number of sound active embryos and their stage of development were identified microscopically per each snail egg mass.

\section{Tested Mosquito}

The vector mosquito, Culex pipiens, was used as test organism. Mosquito eggs were obtained from The Medical Research Institute of Insects. Eggs were soaked in de-chlorinated and filtered tap water to develop into first instar larvae. The larvae reared after this in the same aquarium till development to the third larval stage.

\section{Moulliscicidal and Larvicidal bioassay}

The bioassay was done according to WHO (14) guidelines with slight modifications. Trematoda free; medium sized; active $B$. alexandrina, L. cailliaudi snails and their egg masses as well as late third instar larvae of C. pipiens; 30 in number for each group; were picked up from the aquaria and allocated in three $250 \mathrm{~mL}$ jars for screening the efficacy of the tested plant extracts.

Initially, $2 \mathrm{~mL}$ of each plant distillate was dissolved in $100 \mathrm{~mL}$ distilled water containing $0.3 \%$ Tween 80 to make $1 \%$ stock solution. Immersion technique was adopted according to WHO (14). Efficacy of each tested plant was evaluated using series of upgraded concentrations (400, 200, 100, 50, 25 and 12.5 p.p.m) each for $(3,6,12,24,36$, and 48) hours exposure time. Each experiment set contained three replicates. Control group was run simultaneously for each plant extract with the used solvent material in tap de-chlorinated water. All experiments were conducted simultaneously in the laboratory at room temperature $\left(26 \pm 2^{\circ} \mathrm{C}\right)$.

At the end of the exposure time, tested solution was removed; snails, egg masses and larvae were washed for five times using 
de-chlorinated tap water, kept in a new aquarium for 24 hours post exposure. Mortality was checked using crushing technique (5\% sodium hydroxide solution) as described by WHO (15). Dose of plant extract in part per million (p.p.m) that killed $50 \%$ of the exposed stages $\left(\mathrm{LC}_{50}\right)$ and the dose that killed all of the exposed stages ( $\left(\mathrm{C}_{100}\right)$; were calculated according to Kovendan et al. (16) using the following equation.

Percentage mortality $=\frac{\text { Number of dead snails (larvae) }}{\text { Number of exposed snails (larvae) }} 100$

\section{RESULTS}

Molluscicidal and larvicidal activities of four plant extracts included Grape seed, Eucalyptus, Pomegranate, as well as Verbesina, were tested at upgraded concentrations ranging from (12.5) to (400) p.p.m detecting $\mathrm{LC}_{50}$ and $\mathrm{LC}_{100}$ against Biomphalaria alexandrina; Lymnea cailliaudi snails and their egg masses as well as Culex pipiens larvae.

These extracts included Grape seed extract, Pomegranate alcoholic extract, Verbesina alcoholic extract, Eucalyptus alcoholic extract as well as, Eucalyptus oil. Copper sulphate and Temephos were included as reference moulliscicidal and insecticidal substances $(17,18)$.

The tested plant extracts and oil proved to have moulliscicidal activity but some of them had snail ovicidal as well as larvicidal activity versus $C$. pipiens larvae. Generally; there was a direct relationship between the efficacy and increasing the concentration and exposure time.

Results of the present study cleared that Grape seed extract was able to kill $50 \%$ of the exposed snails $\left(\mathrm{LC}_{50}\right)$ at a concentration of (100 ppm/6-12 h). These concentrations didn't show killing ability versus snail egg masses. In the same time total mortalities of the exposed snails $\left(\mathrm{LC}_{100}\right)$ were achieved using the same previous concentration after increasing the exposure time to $12-24 \mathrm{~h}$.

This extract showed weak effect versus $C$. pipiens larvae, mortality didn't increase over $50 \%$ after increasing the concentration more than (200 ppm for 48h).

Eucalyptus alcoholic extract induced $50 \%$ mortalities in the exposed snails and its egg masses at (100 ppm for 12-24h). Total mortality of $L$. cailliaudi snails and their egg masses was achieved at concentration of (100 ppm) and at (200 ppm) for B. alexandrina snails and their egg masses after $24 \mathrm{~h}$ exposure time.

C. pipiens larvae showed more resistance, as they were able to tolerate higher concentrations of this material more than snails as $\mathrm{LC}_{50} \& \mathrm{LC}_{100}$ of this material reached up to $(200 \mathrm{ppm}$ after 24-48h) exposure time respectively.

The present study recorded rapid effect by Pomegranate alcoholic extract versus $L$. cailliaudi and B. alexandrina snails as $50 \%$ mortality was noticed at (100 ppm) after 3-6 hours exposure. On the contrary $50 \%$ mortalities $\left(\mathrm{LC}_{50}\right)$ for $L$. cailliaudi and B. alexandrina egg masses was recorded at (100-200 ppm) after $24 \mathrm{~h}$ exposure. However, it was 200 ppm for C. piepiens larvae after $48 \mathrm{~h}$ exposure. In the same time Pomegranate alcoholic extract couldn't induce total mortalities neither for both snails' egg masses nor for $C$. pipiens larvae.
Total mortalities $\left(\mathrm{LC}_{100}\right)$ of $L$. cailliaudi and its egg masses was revealed after using $100 \mathrm{ppm}$ after $24 \mathrm{~h}$ exposure of Verbisina alcoholic extract, higher concentration (200 ppm) for the same exposure time was required to get complete mortality for $B$. alexandrina snail and their egg masses. While 200 ppm after $48 \mathrm{~h}$ was required for achieving total mortality of $C$. pipiens larvae.

The present study determined 100 ppm/12h as $L_{100}$ for Eucalyptus oil versus $L$. cailliaudi snails and its egg masses. While 200ppm was required for the $L_{100}$ versus $B$. alexandrina, after $12 \mathrm{~h}$. The concentration of (200 ppm/48h) was considered as LC $_{100}$ of the oil versus $B$. alexandrina egg masses as well as $C$. pipiens.

It is worth to be mentioned that the moulliscicidal activity of the studied plant extracts was higher than the moulliscicdal activity of the reference material (copper sulfate) were its LC $_{50}$ was (5-10 ppm) after 6-12 $\mathrm{h}$ exposure time and its $\mathrm{LC}_{100}$ reached up to (10$20 \mathrm{ppm}$ ) after $24 \mathrm{~h}$. Moreover, the study recorded $\mathrm{LC}_{50}$ and $\mathrm{LC}_{100}$ of the reference insecticide (Temephos) as (0.5) after 24-48 $\mathrm{h}$ exposure time.

No mortalities were recorded in the control non exposed snails in water or in the used alcoholic solvent in each case. Results are presented in the Table 1.

\section{DISCUSSION}

Different snails and mo squitoes' species are of the most important vectors transmitting diseases all over the world; that constitute health problems and remaining as leading causes of mortality (19). Development of molluscicidal and insecticidal substances of botanical origin may serve as suitable alternatives to synthetic ones (17). Although several plants from different families have been reported for their molluscicidal and insecticidal activities, only few botanicals have moved from the laboratory to field use (20). In Egypt, screening of local plants for molluscicidal \& mosquito larvicidal activities had received increasing attention (21). This was also previously reported by $(22,23)$.

Grape seed, Eucalyptus, Pomegranate, Verbesina alcoholic extracts, as well as Eucalyptus oil were evaluated in this study. The obtained results $\left(\mathrm{LC}_{100}\right)$ of the tested insecticidal activity of Eucalyptus was closely related to previous studies reported the larvicidal activity of Eucalyptus essential oil and others (24). It was also found that, essential oils of medicinal plants showed different mosquitocidal activities (25). Other studies also recorded that Eucalyptus alcoholic extract had molluscicidal activity (26). However, the present study revealed that Eucalyptus efficacy was less than that of Grape seed and Pomegranate alcoholic extracts. Moreover, C. pipiens larvae resisted its effect. Eucalyptus possesses insect and limited vermin control properties together with repellent properties. Eucalyptus alkaloids exhibited chemosterilant effect in addition to larvicidal and growth inhibition properties (27)

However, Verbesina induced $100 \%$ mortality after $48 \mathrm{~h}$ with higher concentration than that was recorded by other studies (28). Medicinal uses of Verbesina alternifolia appeared to be limited and not widely documented although it was reported that it has an anti-inflammatory action. The major phyto-constituents are terpenoids, flavonoids and aromatic compounds (29). Poisoning 
Table 1. Molluscicidal \&insecticidal effect of plant extracts

\begin{tabular}{|c|c|c|c|c|c|c|c|c|c|c|c|}
\hline \multirow[t]{3}{*}{ No. } & \multirow[t]{3}{*}{ Tested Material } & \multicolumn{5}{|c|}{$\mathrm{LC}_{50}$} & \multicolumn{5}{|c|}{$\mathrm{LC}_{100}$} \\
\hline & & \multicolumn{2}{|c|}{ B. alexandrina } & \multicolumn{2}{|c|}{ L. cailliaudi } & \multirow{2}{*}{\begin{tabular}{|c|} 
C. pipiens \\
Larvae \\
\end{tabular}} & \multicolumn{2}{|c|}{ B. alexandrina } & \multicolumn{2}{|c|}{ L. cailliaudi } & \multirow{2}{*}{\begin{tabular}{|c|} 
C.pipiens \\
Larvae
\end{tabular}} \\
\hline & & snails & $\begin{array}{c}\text { Egg } \\
\text { masses }\end{array}$ & snail & $\begin{array}{c}\text { Egg } \\
\text { masses }\end{array}$ & & snails & $\begin{array}{c}\text { Egg } \\
\text { masses }\end{array}$ & snails & $\begin{array}{c}\text { Egg } \\
\text { masses }\end{array}$ & \\
\hline 1. & Grape Seed Extract & $\begin{array}{l}\text { 100ppm/ } \\
12 \mathrm{~h}\end{array}$ & -ve & $\begin{array}{c}100 \mathrm{ppm} / \\
6 \mathrm{~h}\end{array}$ & -ve & $\begin{array}{c}\text { 200ppm/ } \\
48 \mathrm{~h}\end{array}$ & $\begin{array}{l}\text { 100ppm/ } \\
24 \mathrm{~h}\end{array}$ & -ve & $\begin{array}{l}\text { 100ppm/ } \\
12 \mathrm{~h}\end{array}$ & -ve & -ve \\
\hline 2. & $\begin{array}{l}\text { Eucalyptus Alcoholic } \\
\text { Extract }\end{array}$ & $\begin{array}{l}\text { 100ppm } \\
12 \mathrm{~h}\end{array}$ & $\begin{array}{l}\text { 100ppm } \\
24 \mathrm{~h}\end{array}$ & $\begin{array}{l}\text { 100ppm } \\
12 \mathrm{~h}\end{array}$ & $\begin{array}{c}\text { 100ppm } \\
12 \mathrm{~h}\end{array}$ & $\begin{array}{l}\text { 200ppm/ } \\
24 \mathrm{~h}\end{array}$ & $\begin{array}{l}\text { 200ppm/ } \\
18 \mathrm{~h}\end{array}$ & $\begin{array}{l}200 \mathrm{ppm} / \\
24 \mathrm{~h}\end{array}$ & $\begin{array}{l}\text { 100ppm } \\
24 \mathrm{~h}\end{array}$ & $\begin{array}{l}\text { 100ppm } \\
24 \mathrm{~h}\end{array}$ & $\begin{array}{c}\text { 200ppm/ } \\
48 \mathrm{~h}\end{array}$ \\
\hline 3. & $\begin{array}{l}\text { Pomegranate } \\
\text { Alcoholic Extract }\end{array}$ & $\begin{array}{c}\text { 100ppm/ } \\
6 \mathrm{~h}\end{array}$ & $\begin{array}{l}\text { 200ppm/ } \\
24 \mathrm{~h}\end{array}$ & $\begin{array}{l}\text { 100ppm/ } \\
3 \mathrm{~h}\end{array}$ & $\begin{array}{l}\text { 100ppm/ } \\
24 \mathrm{~h}\end{array}$ & $\begin{array}{c}\text { 200ppm/ } \\
48 \mathrm{~h}\end{array}$ & $\begin{array}{l}\text { 100ppm/ } \\
18 \mathrm{~h}\end{array}$ & -ve & $\begin{array}{l}\text { 100ppm/ } \\
12 \mathrm{~h}\end{array}$ & -ve & -ve \\
\hline 4. & $\begin{array}{l}\text { Verbesina Alcoholic } \\
\text { Extract }\end{array}$ & $\begin{array}{l}\text { 200ppm/ } \\
12 \mathrm{~h}\end{array}$ & -ve & $\begin{array}{l}\text { 100ppm/ } \\
12 \mathrm{~h}\end{array}$ & $\begin{array}{l}\text { 100ppm/ } \\
24 \mathrm{~h}\end{array}$ & $\begin{array}{c}\text { 200ppm/ } \\
12 \mathrm{~h}\end{array}$ & $\begin{array}{l}\text { 200ppm/ } \\
24 \mathrm{~h}\end{array}$ & $\begin{array}{l}200 \mathrm{ppm} / \\
24 \mathrm{~h}\end{array}$ & $\begin{array}{l}\text { 100ppm/ } \\
24 \mathrm{~h}\end{array}$ & $\begin{array}{l}\text { 100ppm/ } \\
24 \mathrm{~h}\end{array}$ & $\begin{array}{c}\text { 200ppm/ } \\
48 \mathrm{~h}\end{array}$ \\
\hline 5. & Eucalyptus oil & $\begin{array}{c}\text { 100ppm/ } \\
12 \mathrm{~h}\end{array}$ & $\begin{array}{l}200 \mathrm{ppm} / \\
24 \mathrm{~h}\end{array}$ & $\begin{array}{c}\text { 50ppm/ } \\
24 \mathrm{~h}\end{array}$ & $\begin{array}{l}\text { 50ppm/ } \\
12 \mathrm{~h}\end{array}$ & $\begin{array}{c}\text { 200ppm/ } \\
24 \mathrm{~h}\end{array}$ & $\begin{array}{l}\text { 200ppm/ } \\
12 \mathrm{~h}\end{array}$ & $\begin{array}{l}200 \mathrm{ppm} / \\
48 \mathrm{~h}\end{array}$ & $\begin{array}{c}\text { 100ppm/ } \\
12 \mathrm{~h}\end{array}$ & $\begin{array}{c}\text { 100ppm/ } \\
12 \mathrm{~h}\end{array}$ & $\begin{array}{c}\text { 200ppm/ } \\
48 \mathrm{~h}\end{array}$ \\
\hline 6. & $\begin{array}{l}\text { Reference } \\
\text { Molluiscicide } \\
\text { (Cu Sulphate) }\end{array}$ & $\begin{array}{c}\text { 10ppm/ } \\
12 \mathrm{~h}\end{array}$ & $\begin{array}{c}\text { 10ppm/ } \\
8 \mathrm{~h}\end{array}$ & $\begin{array}{c}5 p p m / \\
6 h\end{array}$ & $\begin{array}{c}\text { 10ppm/ } \\
6 \mathrm{~h}\end{array}$ & -ve & $\begin{array}{c}\text { 20ppm/ } \\
24 \mathrm{~h}\end{array}$ & $\begin{array}{c}\text { 20ppm/ } \\
24 \mathrm{~h}\end{array}$ & $\begin{array}{c}\text { 10ppm/ } \\
24 \mathrm{~h}\end{array}$ & $\begin{array}{c}\text { 10ppm/ } \\
24 \mathrm{~h}\end{array}$ & -ve \\
\hline 7 & Reference Insecticide & - & - & - & - & $\begin{array}{l}0.5 \mathrm{ppm} / \\
24 \mathrm{~h}\end{array}$ & - & - & - & - & $\begin{array}{c}0.5 \mathrm{ppm} / \\
48 \mathrm{~h}\end{array}$ \\
\hline
\end{tabular}

caused by Verbesina may be corresponded to high levels of nitrates and galegine (30).

The present study revealed that Grape seed and Pomegranate alcoholic extracts had potent molluscicidal activity. They caused significant behavioral changes in B. alexandrina and L. cailliaudi with the most obvious sign of distress being muscular and spiral twisting of the body, followed by crawling on one another. The nature and rapid onset of these behavioral responses shows the extracts probably contains neurotoxins, which amongst other things, might be active at the neuromuscular system of the exposed animals. Some of these characters were previously described (31).

In the author's opinion and in agreement with previous studies, Grape seed extract proved molluscicidal effect could be accepted as it possesses a wide array of pharmacological and biochemical actions (32). This includes anti-inflammatory, anticarcinogenic activities. Moreover, it inhibits enzymes involved in the formation of histamine which might be attributed to its rich content of Proanthocyanidins.

Phytochemistry and pharmacological activities of Pomegranate (Punica granatum) were previously described (33). Medicinal properties are; antioxidant, anticancer, anti-inflammatory, antibacterial/antimicrobial and anthelmintic (34). Moreover, it was reported that Pomegranate extract gave very promising results as an anti-trichomoniasis virginalis (35). Pomegranate contains high levels of phytochemicals including polyphenols, sugars, fatty acids, aromatic compounds, amino acids, tocopherols, sterols, terpenoids and alkaloids (36).

Generally, mortality to the plant distillates increased as concentration and exposure time increased (37). This could be due to that uptake of active moiety is time dependant, leading to progressive increase of entrance of the volatile oil and its effect in the snail body (20).
Molluscicides affect snails through inhibition of its respiratory enzymes either by direct contact or affecting the metabolic activities of snails (38). They act on different enzymes mainly those of respiration and carbohydrate metabolism. Inhibition of acetylcholinestrase enzyme, increasing its concentration at the synapses, leading to paralysis and eventually death (21). The adverse effect of these plant extracts can be accepted through such a mode of action. This was proved by appearance of $L$. cailliaudi as more sensitive than $B$. alexandrina snails.

This might be attributed to several factors; as L. cailliaudi has a wide aperture and large flappy body that needs more oxygen for the vital processes. As the majority of fresh water snails took their oxygen requirements throughout cutaneous pseudo bronchial and via pulmonary respiration. This is accompanied by high oxygen consumption level in comparison with $B$. alexandrina which has small snail body easily contracted inside snail with narrow aperture that protect its soft part of the body which is easily affected by the surrounding solution in comparison with the lower part of the body (snail foot) (21).

Moreover, sensitivity of $L$. cailliaudi egg masses in comparison with that of $B$. alexandrina may be related to that $L$. cailliaudi egg is large in size with thin transparent ootheca in comparison with that of $B$. alexandrina which is small in size with thick ootheca (21).

It is worth to be mentioned that bioactivity of plant extracts and essential oils is affected by the plant species, cultivation conditions, plant storage, plant preparation and methods of extraction (39).

No behavioral symptoms or death occurred in control groups, indicating that no factors other than plant moieties were responsible for the altered behavior and mortality. 
The present study revealed that all of the tested plant extracts had molluscicidal effect as well as snail ovicidal and C.pipiens larvicidal effect of some of them with high $\mathrm{LC}_{50}$ and $\mathrm{LC}_{100}$ in comparison with reference molluscicide (Copper Sulphate) and insecticide (Temephos) substances. This might be explained as the identified characters of the examined plant extracts were evaluated (on the level of the present study) as crude non- selectively concentrated extracts while the used reference substances were more purified. So free using of commercially purified, extraction of botanical molluscicidal and insecticidal active component, is considered to be a new field of preparation of safe, rapidly biodegradable and eco-friendly alternative to chemical ones $(22,40)$.

\section{Acknowledgement}

The authors are indebted and grateful to Dr. M. M. Salama, Department of Pharmacognosy, Faculty of Pharmacy, Cairo University, for preparing and supplying the plant extracts and for her support and advices.

\section{Conflict of Interest}

No conflict of interest was declared by the authors.

\section{REFERENCES}

1. Githiori JB, Athanasiadou S, Thamsborg SM. Use of plants in novel approach for control of gastrointestinal helminthes in livestock with emphasis on small ruminants. Vet Parasitol 2006; 139: 308-20. [CrossRef]

2. Shaalan EA, Canyon D, Younes MW, Abdel-Wahab H, Mansour AH Effects of sub-lethal concentrations of synthetic insecticides and Callitris glaucophylla extracts on the development of Aedes aegypti. J Vector Ecol 2005; 30: 295-8.

3. WHO (World Health Organization). The control of Schistosomiasis. Tech. Rep. 1985. 728, WHO, Geneva, Switzerland.

4. Cetin H, Yanikoglu AA. Study of the larvicidal activity of Origanum (Labiatae) species from southwest Turkey. J Vector Ecol 2006; 31: 118-22. [CrossRef]

5. Paul A, Harrington LC, Zhang L, Scott JG. Insecticide resistance in Culex pipiens from New York. J Am Mosq Control Assoc 2005; 21: 305-9. [CrossRef]

6. Davis A. Schistosomiasis. In GC Cook, Manson's Tropical Diseases, 20th Edn., WB Saunders Company td, London 1996. PP: 1413-56.

7. King $\mathrm{CH} \&$ Dangerfield-Cha $\mathrm{M}$. The unacknowledged impact of chronic schistosomiasis. Chronic Illness 2008; 4: 65-79. [CrossRef]

8. Pereira AR, McCue CF, Gerwick WH. Cyanolide A, a Glycosidic Macrolide with Potent Molluscicidal Activity from the Papua New Guinea Cyanobacterium Lyngbya bouillonii. J Nat Prod 2010; 26: 217-20. [CrossRef]

9. WHO (World Health Organization):"The control of Schistosomiasis". Tech. Rep. 1993. 830, WHO, Geneva, Switzerland.

10. Lahlou M. Composition and molluscicidal properties of essential oils of five Moroccan Pinaceae. Pharm Biol 2003; 41: 207-10. [CrossRef]

11. Cetin H, Yanikoglu A. A study of the larvicidal activity of Origanum (Labiatae) species from southwest Turkey. J Vector Ecol 2006; 31: 118-122. [CrossRef]

12. Araújo EC, Silveira ER, Lima MA, Neto MA, de Andrade IL, Lima MA, et al. Insecticidal activity and chemical composition of volatile oils from Hyptis martiusii Benth. J Agric Food Chem 2003; 51: 3760-2. [CrossRef]

13. Christensen NO \& Frandsen A. An introduction to the taxonomy, morphology, biology and transmission ecology of species of the genus Schistosoma causing human African schistosomiasis. 1985. Danish Bilharsiasis Laboratory, Denmark.
14. WHO Report of the WHO in formal consultation on the evaluation and on the testing of insecticides. 1996; CTD/WHO PES / IC/96.1, 69

15. World Health Organization Guidelines for laboratory and Field Testing of mosquito larvicides 2005; WHO.WHO/CDS/WHOPES/ GCDPP.13WHO, Geneva, Switzerland.1-39.

16. Kovendan K, Murugan K, Panneerselvam C, Kumar PM, Amerasan $D$, Subramaniam J, et al. Laboratory and field evaluation of medicinal plant extracts against filarial vector, Culex quinquefasciatus Say (Diptera: Culicidae). Parasitol Res 2011.

17. Santos EA, de Carvalho CM, Costa ALS, Conceição AS, Moura FBP Santana AEG. Bioactivity Evaluation of Plant Extracts Used in Indigenous Medicine against the Snail, Biomphalaria glabrata, and the Larvae of Aedes aegypti. Evid Based Complement Alternat Med 2012; 2012: 846583

18. Subra R. Biology and control of Culex pipiens Quinqufasciatus Say 1823 (Diptera, Culicidae) with special reference to Africa. Insect Sci Application 1981; 1: 319-38.

19. Kasi S, Komagata O, Tomita T, Sawabe K, Tsuda Y, Kurahashi H, et al. PCR-Identification of Culex pipiens complex collected in Japan. Jpn J Infect Dis 2008; 61: 184-91.

20. Yadav RP, Singh A. Efficacy of Euphorbia hirta latex as plant derived molluscicides against freshwater snails. Rev Inst Med Trop 2011; 53 101-6.

21. Bakry FA. Use of Some Plant Extracts to Control Biomphalaria alexandrina Snails with Emphasis on Some Biological Effects. World Appl Sci J 2009; 6: 1335-45.

22. Youssif RS, Shaalan EA. Mosquitocidal activity of some volatile oils against Aedes caspius mosquitoes. J Vector Borne Dis 2011; 48: 113-5.

23. Oparaocha ET, Iwu I, Ahanakuc JE. Preliminary study on mosquito repellent and mosquitocidal activities of Ocimum gratissimum (L.) grown in eastern Nigeria. Journal of Vector Borne Diseases 2010; 47: 45-50.

24. Traboulsi AF, EL-Haj S, Tueni M, Taoubi K, Nader NB, Mrad A. Repellency and toxicity of aromatic plant extracts against the mosquito Culex pipiens molestus (Diptera: Culicidae). Pest Manag Sci 2005; 61: 596-604. [CrossRef]

25. Prajapati V, Tripathi AK, Aggarwal KK, Khanuja SPS. Insecticidal, repellent and oviposition-deterrent activity of selected essential oils against Anopheles stephensi, Aedes aegypti and Culex quinquefasciatus. Bioresour. Technol 2005; 96: 1749-57. [CrossRef]

26. Hammond JA, Fielding D, Nuru H. Eucalyptus: a sustainable selfdelivery molluscicide? Vet Res Commun 1994; 18: 359-65. [CrossRef]

27. Song A, Wang Y, Liu Y. Study on the chemical constituents of the essential oil of the leaves of Eucalyptus globulus Labill from China. Asian Journal of Traditional Medicines 2009; 4: 134-40

28. Amer A, Mehlhorn H. Larvicidal effect of various essential oils against Aedes, Anopheles, and Culex larvae (Diptera, Culicidae). Parasitol Res 2006; 99: 466-72. [CrossRef]

29. Sindhu, RK, Vasudeva N, Sharma SK. Pharmacognostical and Preliminary Phytochemical Investigations on Verbesina encelioides Benth. Roots. Journal of Herbal Medicine and Toxicology 2010; 4: 113-8.

30. Shluker A. HNIS Report for Verbesina encelioides 2002.

31. Singh A, Agarwal RA. Possibility of using latex of euphorbiales for snail control. The Sci Total Environ 1988; 77: 231-6. [CrossRef]

32. Bagchi D, Sen CK, Ray SD, Das DK, Bagchi M, Preuss HG, Vinson JA Molecular mechanisms of cardioprotection by a novel grape seed proanthocyanidin extract. Mutat Res 2003; 523-524: 87-97. [CrossRef]

33. Lansky EP, Newman RA. Punica granatum (pomegranate) and its potential for prevention and treatment of inflammation and cancer Journal of Ethnopharmacology 2007; 109: 177-206. [CrossRef] 
34. Naovi SAH, Khan MSY, Vohora SB. Antibacterial, anti-fungal and anthelmintic investigations on Indian medicinal plants, Fitoterapia 1991; 62: 221.

35. El-Sherbini GM, Ibrahim KM, El Sherbiny ET, Abdel-Hady NM, Morsy TA. Efficacy of Punica granatum extract on in-vitro and in-vivo control of Trichomonas vaginalis. J Egypt Soc Parasitol 2010; 40: 229-44.

36. Chaturvedula Venkata, Sai Prakash \& Indra Prakash Bioactive Chemical Constituents from Pomegranate (Punica granatum) Juice, Seed and Peel-A Review Int J Res Chem Environ 2011; 1: 1-18.

37. Cetin H, Yanikoglu A, Cilek JA. Larvicidal activity of selected plant hydrodistillate extracts against the house mosquito, Culex pipiens, a West Nile virus vector. Parasitol Res 2011; 108: 943-8. [CrossRef]

38. Singh SK, Singh A. Effects of the plants Thevetia peruviana and Alstonia scholaris (Family: Apocynaceae) on acetylcholinestrase activity of Lymnea acuminate. Egypt. Egyptian J Schisto Infect End Diseas 2003; 25: 31-40.

39. Tawatsin AA, Thavara P, Wongsinkongman U, Bansidhi P, Boonruad $J$, Chavalit-tumrong $T$, et al. Repellency of essential oils extracted from plants in Thiland against four mosquito vectors (Diptera: Culicidae) and oviposition deterrent effects against Aedes aegypti (Diptera: Culicidae). Souteast Asian J Trop Med Public Health 2006; 37: 915-31.

40. Schall VT, Vasconcellos MC, Rocha RS, Souza CP, Mendes NM. The control of the schistosome-transmitting snail Biomphalaria glabrata by the plant Molluscicide Euphorbia splendens var. hislopii (syn milli Des. Moul): a longitudinal field study in an endemic area in Brazil. Acta Trop 2001; 79: 165-70. [CrossRef] 